\title{
KhoiSan Indigeneity and Entangled Becomings with Kanna, a Teacher Plant
}

\author{
Diana Gibson \\ University of Western Cape \\ dgibson@uwc.ac.za
}

Considering indigeneity, colonialism, and/or colonial settler histories alongside and with medicinal plants, my research focuses on a Southern African setting and engages with partial connections, intersections, contradictions, and shifts concerning traditional, botanical, medical, and scientific knowledge regarding medicinal plants. Many Indigenous people conceptualize plants as animate, active beings, able to know and communicate (Toro, 2016). Scientific studies, seemingly breaking from their past reductionist understandings of plants, have also increasingly begun to intimate the complexity of the aptitude, connectivity, and learning ability of plants (Chamovitz, 2013). Engaging with these distinct ways of knowing plants, my research troubles human perceptions of subjectivity by approaching plants as having vegetative, nonhuman agency. Thus, I take plants seriously by addressing their world-making impact and actions in human and nonhuman collectives.

Plants also unsettle our own preconceived considerations of human-centered periodicity and temporality. Learning from and generating critical descriptions of particular medicinal plants (Tsing, 2014), my research traces Kanna, or Kougoed, plants known by Indigenous San and Khoi and their generative, multifaceted, and intertwined history with humans. As assigned members of a botanical plant family named Mesembryanthemaceae and species called Sceletium turtuousum, Kanna succulent plants disconcert our timelines and human foci. For millions of

\footnotetext{
Gibson, Diana (2019). KhoiSan indigeneity and entangled becomings with Kanna, a teacher plant. Catalyst: Feminism, Theory, Technoscience, 5(2), page 1-5. 
years they have shaped lively, biodiverse assemblages in harsh conditions, adopted multiple and various forms, developed photosynthetic and other unique life strategies in and with arid landscapes, intermittent rainfall, poor soil, and high irradiation, and have thrived in life-creating multispecies entanglements with other plants, microbes, insects, reptiles, birds, and micromammals (Ihlenfeldt, 1994).

Kanna are also enmeshed in shifting socio-ecological relations with human and other nonhuman beings, affecting and being affected by pre- and postcolonial economic and political relations that have obscured San and Khoi ways of knowing the plant. To understand and demonstrate these relations, I investigate certain knowledges and practices related to Kanna and how the plants have become entangled with and enrolled by San and Khoi people in pre-colonial Southern Africa through particular situated practices of meaning-making, knowing, and being regarding healing and well-being. For instance, Khoi control over areas where Kanna grew abundantly enhanced the power and authority of an Inqua leader named Hijkon (Gei!khub) (Newton-King, 1999) as Khoi prized the plant for its soothing and calming capacity, while European ships encountering San and Khoi sought Kanna as a valuable variety of sought-after ginseng (Gericke, 2018). Colonial settlement and trade brought about movements of plants, introduced new varieties, changed the environment, dispossessed San and Khoi people of land, and decimated people and plants both culturally and physically. It also brought Kanna into the herbal worlds of colonial pharmacopeia. Colonial explorers and settlers transplanted local plant species to other parts of the world and, as a result, Kanna simultaneously engendered and engaged new assemblages of physicians, chemists, and pharmacists interested in Kanna's narcotic potentiality. As Kanna was further represented and studied within authoritative and scientific knowledge domains of botany and chemistry, it became known around 1775 as a single botanical entity from nature, named Sceletium turtuousum in the 1960s, and was further reduced from 1995 as constitutive of its active molecules (e.g., Mesembrine); in each instance, Khoi and San medicinal knowledge of Kanna was obscured and relegated to mere footnotes. In my research, I understand and demonstrate these scientific practices as contributing to the subordination of Khoi and San peoples, and as informing later histories of apartheid that devalued Khoi and San identities by legally classifying them as "colored people."

Connecting these plant-human histories to contemporary San and Khoi political struggles, my research also asks how the materiality and vital capacities of Kanna relationally reconfigured identities and comings-together through the signing of a 
prior informed consent benefit-sharing agreement between the South African San Council and Namaqualand communities of Nourivier and Paulshoek and the South African-based HGH Pharmaceuticals company. Specifically, the agreement sought benefits derived from HGH Pharmaceuticals' study and commercialization of Sceletium tortuosum extracts as a complementary medicine for stress relief and mood elevation, reportedly a positive case study of a product derived from Indigenous Peoples' knowledge (Gericke, 2018).

Finally, I trace ways in which people dwell and "become" with plants. San and Khoi ingested Kanna for their euphoric effect, thereby interpenetrating assumed boundaries between plants and human, and transforming plant and human selves. Since 1995 such cross-species associations and movements were pursued between descendants of Khoi and medical researchers in embodied efforts to come to know, and experience human-Kanna interconnectedness and engage Kanna as subjects in collective enquiry: as teachers, opening the mind and enhancing euphoria.

This research engages Kanna as subjects in collective inquiry, as teachers and interlocutors. To do so, I elaborate and draw on KhoiSan ideas about plant sentience, being, and spirituality. While plants have histories closely entangled with people, they also unsettle human periodicity.

\section{Acknowledgements}

My gratitude to the people who inspired me and kindly contributed to my study. The research is funded by a Senate Research Grant, University of the Western Cape.

\section{References}

Chamovitz, D. (2013). What a plant knows: A field guide to the senses. New York, NY: Scientific American.

Gericke, N. (2018). Kabbo's !Kwaiń: The past, present and possible future of kanna. In D. McKenna, G. T. Prance, W. Davis, \& B. De Leonen (Eds.), The ethnopharmacological search for psychoactive drugs (pp. 122-150). Sante Fe, NM: Synergetic Press.

Ihlenfeldt, H.-D. (1994). Diversification in an arid world: The Mesembryanthemaceae. Annual Review of Ecology and Systematics, 25, 521-546.

Newton-King, S. (1999). Masters and servants on the Cape Eastern Frontier, 17601803. Cambridge: Cambridge University Press. 
Toro, A. (2016). Interview with Philippe Descola. Suomen Antropologi, 41(1), 15-25.

Tsing, A. (2014). More-than-human sociality: A call for critical description. In K.

Hastrup (Ed.), Anthropology and nature (pp. 27-42). New York, NY: Routledge.

\section{Author Bio}

Diana Gibson is an anthropologist specializing in medical anthropology. She has published nationally and internationally on a variety of issues related to health, illness and healing and has a deep interest in medicinal plants and human-plant relations. 